Revista Brasileira de Meteorologia, v.28, n.2, 125 - 128, 2013

\title{
ANALYSIS OF THERMAL CONDUCTIVITY IN A SEASONAL FLOODED FOREST IN THE NORTHERN PANTANAL
}

\author{
LEONE FRANCISCO AMORIM CURADO, THIAGO RANGEL RODRIGUES, ALLAN GONÇALVES \\ DE OLIVEIRA, JONATHAN WILLIAN ZANGESKI NOVAIS, IRAMAIA JORGE CABRAL DE PAULO, \\ MARCELO SACARDI BIUDES E JOSÉ DE SOUZA NOGUEIRA
}

\author{
Universidade Federal de Mato Grosso, Instituto de Física (UFMT/IF), Cuiabá, MT, Brasil
}

leone@pgfa.ufmt.br, thiagorangel@pgfa.ufmt.br, allan@pgfa.ufmt.br, jonathan@pgfa.ufmt.br, ira@ufmt.br, marcelo_biudes@yahoo.com.br,nogueira@ufmt.br

Received August 2010 - Accepted October 2012

\begin{abstract}
Research involving the flux of energy in the soil has been intensified in order to increase the understanding of the geophysical behavior of the Pantanal-Brazil. In present study was examined the seasonal variation of the thermal soil conductivity in the Pantanal for the study of energy flow in the soil to Pantanal region. The average values obtained by the Fourier equation showed that the soil thermal conductivity in the wet and dry seasons was $8.69 \mathrm{~W} \cdot \mathrm{m}^{-1} .{ }^{\circ} \mathrm{C}^{-1}$ and $6.65 \mathrm{~W} \cdot \mathrm{m}^{-1} \cdot{ }^{\circ} \mathrm{C}^{-1}$ respectively. The seasonal variation of the thermal conductivity of the soil was $30.68 \%$ higher in the wet season than in the dry season due to soil moisture in the wet season. It was also noted that the seasonal variation of temperature in the soil layer was higher in the wet season than in the dry season due to a lower incidence of solar radiation in this season.
\end{abstract}

Keywords: Energy flux, geophysical behavior, Fourier Equation

RESUMO: ANÁLISE DA CONDUTIVIDADE TÉRMICA EM FLORESTA ALAGADA SAZONALMENTE NO NORTE DO PANTANAL

Pesquisas envolvendo o fluxo de energia no solo têm-se intensificado, a fim de que se conheça o comportamento geofísico do Pantanal. No presente trabalho buscou-se verificar a variação sazonal da condutividade térmica do solo no Pantanal Mato-Grossense, com a finalidade de contribuir para as pesquisas destinadas ao estudo do fluxo de energia no solo na região pantaneira. Os valores médios obtidos através da equação de Fourier mostraram que a condutividade térmica do solo no período chuvoso e seco foi, respectivamente, $8,69 \mathrm{~W} \cdot \mathrm{m}^{-1} \cdot{ }^{\circ} \mathrm{C}^{-1} \mathrm{e} 6,65 \mathrm{~W} \cdot \mathrm{m}^{-1} \cdot{ }^{\circ} \mathrm{C}^{-1}$. A variação sazonal da condutividade térmica do solo foi $30,68 \%$ maior no período chuvoso do que no seco, em decorrência da maior quantidade de água no solo na estação chuvosa. Observou-se também, que houve variação sazonal da temperatura do solo nas camadas estudadas, sendo maior no período chuvoso do que no seco, devido à menor incidência de radiação solar nesse período.

Palavras Chaves: Fluxo de Energia. Comportamento Geofísico. Equação de Fourier

\section{INTRODUCTION}

The Brazilian Pantanal is the largest flood plain of the planet. In Brazilian territory, it has almost $140.000 \mathrm{Km}$, which corresponds to $1.6 \%$ of Brazilian territory (Curado et al., 2011). The geophysical structure of the Pantanal is composed by large alluvial plains and deltas in the basin of Paraguay as a link between the biomes of the Amazon, Brazilian Savanna, Chaco and Atlantic Forest (Amador, 2006).
Its rich biodiversity is sustained by a high variability of hydrologic and edaphic habitat conditions. Extensive cattle farming, adapted to the flooding cycles, is the predominant land use inside the Pantanal. Human activity in its contributing watersheds, however, endangers the floodplain environmental integrity, increasing, for example, the sediment (Wantzen, 2006), nutrient (Zeilhofer et al., 2006).

Due to its vast diversity, Pantanal has its own characteristics. The climate is characterized by having periods 
of floods and dry that alternate throughout the year allowing the formation of a monodominant prolonged period due to frequent flooding and poor soil drainage site. At the other extreme, dry periodically causes water stress on local vegetation, regulating the phenology and mass production. The high growth of vegetation, coupled with temporal variation of meteorological elements, contributes to variation in energy exchange between the surface and atmosphere (Bellaver, 2010).

Knowledge of geothermal variation flow, induced by solar radiation in the upper layers, is very important for Geosciences, because these depths constitute the main stage of many geochemical processes, especially weathering and laterization, and geophysical processes, such as changes in values of thermal conductivity and diffusivity in the zone of aeration (Araújo et al., 2004).

Process regulate soil behavior, knowledge of heat flux is necessary to understand its components, like a diffusion of solutes and gases, the development of plants such as seed germination Zucareli et al. (2010), water assimilation and nutrients by roots, and the microorganism activity in the soil, which depend directly on the propagation of heat, and the study of seasonality, for the analysis of the influence of water in this heat propagation.

Thus, the aimed of the study was estimate the thermal soil conductivity in the northern region of the Pantanal in two seasons.

\section{MATERIALS AND METHODS}

The study was conducted in an area located in a Private Natural Heritage Reserve - PNHR SESC - PANTANAL, at Barão de Melgaço MT-Brazil, 160 km far from Cuiabá - MT, where it was installed a micrometeorological tower $32 \mathrm{~m}$ high $\left(16^{\circ} 39^{\prime} 50^{\prime \prime} \mathrm{S}, 56^{\circ} 47^{\prime} 50^{\prime \prime} \mathrm{W}\right)$ and at an altitude of $120 \mathrm{~m}$. The vegetation in this area is monodominant of Cambará (Vochysia divergens, Phol), known locally as cambarazal with canopy height varying between $28-30 \mathrm{~m}$.

The soil was classified as Haplic Gleysoil (EMBRAPA, 1997). The weather is type Aw, with corresponding dry winters and rainy summers. Its annual temperature oscillates between $22^{\circ} \mathrm{C}$ to $32^{\circ} \mathrm{C}$, and the annual mean precipitation is $1150 \mathrm{~mm}$.

The micrometeorological tower had termistors installed at $0.03 \mathrm{~m}$ and $0.07 \mathrm{~m}$ depth, , a fluximeter (Campbell HFT3 Soil Heat Flux Plate) at $0.05 \mathrm{~m}$ depth, a piranometer model Li 200X (Li-cor Bioscience, Inc., Lincoln, NE, USA) and a datalogger model CR 10X (Campbell Scientific, Inc., Logan, Utah,USA).

For this study, it was used data collected between the months January to September 2008. The months between January to April corresponds to the wet season and between June to September, dry season. The month of May was not considered to be a transition period between the two seasons. The instruments used for data collection were programmed to make measurements every 15 minutes, and were daily averages of these values.

According to Reichardt and Timm (2004), the thermal conductivity, K, can be defined by equation of Fourier, where the density of soil heat flux, $\mathrm{q}\left(\mathrm{W} \cdot \mathrm{m}^{-2}\right.$.), is proportional to the temperature gradient at depth $\mathrm{z}, \mathrm{dT} / \mathrm{dz}\left({ }^{\circ} \mathrm{C} \cdot \mathrm{m}^{-1}\right)$, this equation can be written:

$$
\begin{gathered}
q=-K \frac{d T}{d z} \\
K=-\frac{q}{d T / d z}
\end{gathered}
$$

where, $q$ is density of soil heat flux $\left(\mathrm{W} \cdot \mathrm{m}^{-2}\right), \mathrm{dT} / \mathrm{dz}$ is the gradient of temperature in soil $\left({ }^{\circ} \mathrm{C} . \mathrm{m}^{-1}\right)$ and $\mathrm{K}$ is the thermal soil conductivity $\left(\mathrm{W} \cdot \mathrm{m}^{-1} .{ }^{\circ} \mathrm{C}\right)$

\section{RESULTS AND DISCUSSIONS}

Daily values averages of soil thermal conductivity (K), soil heat flux $(\mathrm{G})$, gradient of temperature between depths of $0.03 \mathrm{~m}$ and $0.07 \mathrm{~m}(\mathrm{dT} / \mathrm{dz})$ and temperatures at $0.03 \mathrm{~m}$ and 0.07 $\mathrm{m}$, in the wet and dry seasons it was showed in Table 1.

In the covered ground it is assumed that there is greater moisture content changing the specific heat and thermal conductivity of the soil. Thus, as the specific heat of water is $\operatorname{high}\left(4,18 \mathrm{MJ} \cdot \mathrm{m}^{-3} \cdot \mathrm{K}^{-1}\right)$ the thermal capacity of the soil increases with increasing moisture content (Shoffel and Mendes, 2005).

Higher values of soil temperature increase the kinetic energy of water molecules and cause dispersion. If there is

Table 1 - Values of thermal conductivity $(K)$, soil heat flux $(G)$, temperature gradient $(\mathrm{dT} / \mathrm{dz})$, temperature in $0.03 \mathrm{~m}$ (T3) and

\begin{tabular}{|c|c|c|c|c|c|}
\hline \multicolumn{6}{|c|}{ Dry Season } \\
\hline & $\mathbf{K}$ & G & $\mathrm{dT} / \mathrm{dz}$ & T3 & T7 \\
\hline & $\left(\mathbf{W} \cdot \mathbf{m}^{-1} \cdot{ }^{\circ} \mathbf{C}^{-1}\right)$ & $\left(W \cdot \mathbf{m}^{-2}\right)$ & $\left({ }^{\circ} \mathrm{C} . \mathrm{m}^{-1}\right)$ & $\left({ }^{\circ} \mathrm{C}\right)$ & $\left({ }^{\circ} \mathrm{C}\right)$ \\
\hline Maximum & 24.13 & 0.08 & 0.02 & 30.67 & 30.51 \\
\hline Minimum & -15.24 & 0.001 & -0.08 & 28.08 & 27.93 \\
\hline Average & 8.69 & 0.03 & -0.03 & 29.43 & 29.32 \\
\hline \multicolumn{6}{|c|}{ Wet Season } \\
\hline & $\mathbf{K}$ & $\mathbf{G}$ & $d T / d z$ & T3 & T7 \\
\hline & $\left(\mathbf{W} \cdot \mathbf{m}^{-1} \cdot{ }^{\circ} \mathbf{C}^{-1}\right)$ & $\left(\mathbf{W} \cdot \mathbf{m}^{-2}\right)$ & $\left({ }^{\circ} \mathrm{C} . \mathrm{m}^{-1}\right)$ & $\left({ }^{\circ} \mathbf{C}\right)$ & $\left({ }^{\circ} \mathrm{C}\right)$ \\
\hline Maximum & 15.83 & 0.18 & 0.11 & 27.98 & 26.92 \\
\hline Minimum & -26.63 & 0.002 & -0.29 & 22.03 & 22.22 \\
\hline Average & 6.66 & 0.10 & -0.15 & 25.99 & 25.40 \\
\hline
\end{tabular}
temperature in $0.07 \mathrm{~m}$ (T7) in the wet and dry seasons. 


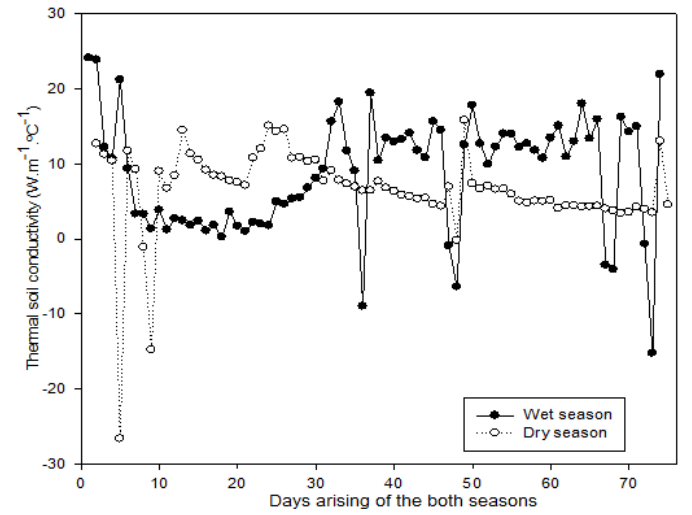

Figure 1 - Thermal soil condutivicty in the wet and dry seasons.

variation in soil moisture, there will be variation in thermal conductivity and consequently affects the temperature distribution in the soil. There is an increase of thermal conductivity with high soil moisture, because the voids present in the soil structure are filled with water that has higher thermal conductivity than air present in the soil.

According to Figure 1 and Table 1, the average thermal conductivity was higher in the wet season. Due to higher soil moisture in this season, which increases heat transport, however, if the porous parts of the soil in the dry season, which are practically filled with air, becomes filled with water in wet season, which allows for greater heat transport by conduction is the primary means of heat transport in soil. This result is in agreement with the thermal conductivity of the soil.

The higher thermal conductivity the lower the variation of surface temperature and the greater the heat storage. The thermal conductivity depends on soil texture, porosity and moisture. Then it varies from soil to soil and for the same soil, according to its soil moisture, is a factor that significantly affects the its thermal conductivity.

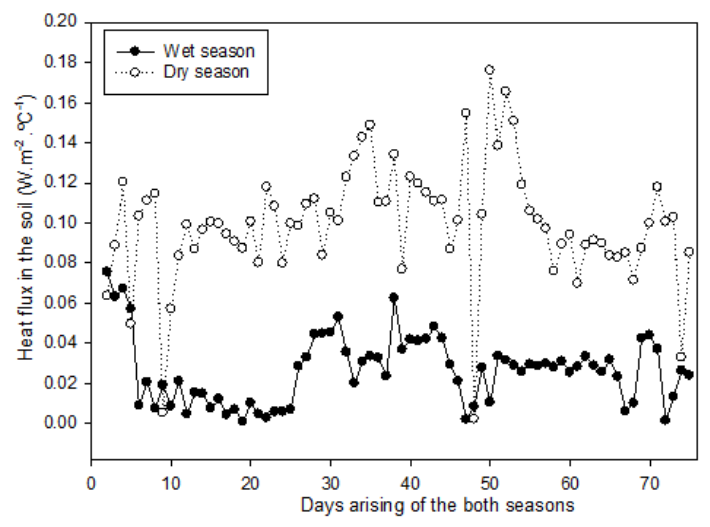

Figure 2 - Heat flux in the soil in the wet and dry seasons.
Hydromorphic soils have a lower thermal conductivity than sandy soils, showing that the density also influences the values of thermal conductivity. Similarly, for the same land with the same density, when the water content increases, the thermal conductivity increases as well (Abu-Hamdeh et. al., 2001).

Based on Table 1 and Figures 2 and 3, it can be observed that the soil heat flux and temperature gradient had higher mean absolute values in the dry season which caused a reduction in the average value of thermal conductivity, Equation 2, in the same season.

It can be also seen that the soil thermal conductivity in the dry period was approximately $30.68 \%$ lower than in the wet season. This reduction was due to a further increase of temperature gradient, approximately $400 \%$ higher in the dry season, in relation to the increasing the soil heat flux in the same season, that was about $233.33 \%$ higher. As in (1) the temperature gradient (dT / dz) appears in the denominator, its largest increase over the soil heat flux $(\mathrm{G})$ caused a decrease in thermal conductivity of soil in the dry season.

In Figures 4 and 5 , the variation of the temperature at depths of $0,03 \mathrm{~m}$ and $0,07 \mathrm{~m}$ in the wet and dry seasons is showed. It was observed that in the layer closest to the ground there was a reduction in the average values of about $3.44{ }^{\circ} \mathrm{C}$ in the dry season, which represented $13.24 \%$ of the temperature of that season and the layer of $0.07 \mathrm{~m}$ there was a reduction of 3.92 ${ }^{\circ} \mathrm{C}$, which represented $15.43 \%$ of the temperature of the dry season, that is, an increase of $0.48{ }^{\circ} \mathrm{C}$ between layers of 0.03 $\mathrm{m}$ and $0.07 \mathrm{~m}$, hence the increase in the temperature gradient between the layers studied.

\section{CONCLUSION}

There was seasonal variation of thermal conductivity in the studied area. The thermal conductivity in the wet season was approximately $30.68 \%$ higher than in the dry season.

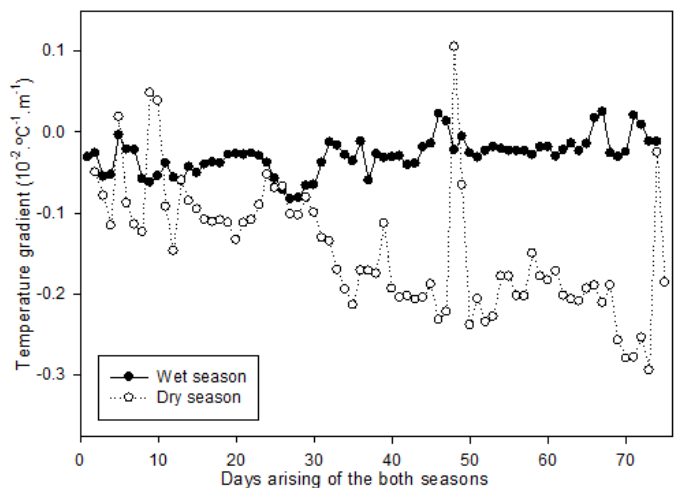

Figure 3 - Temperature gradient between $0,03 \mathrm{~m}$ and $0,07 \mathrm{~m}$ of depth in the wet and dry seasons. 


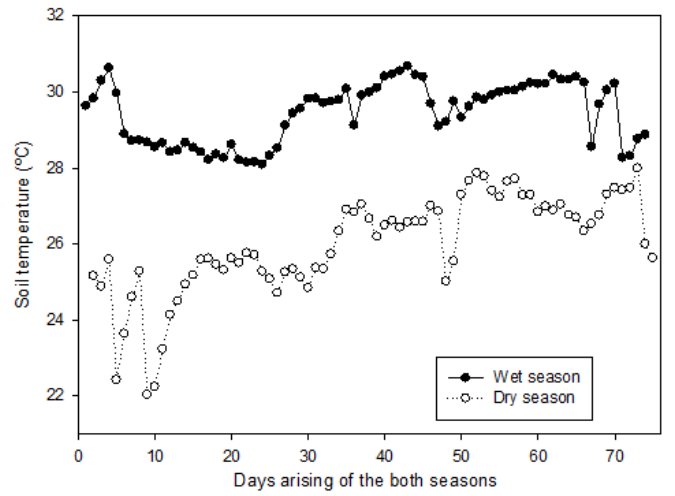

Figure 4 - Variation of the soil temperature in $0,03 \mathrm{~m}$ depth in the wet and dry seasons.

The temperature gradient had a high increase in the dry season compared to the increase of heat flow in soil. The temperature between the two layers analyzed showed an increase of $0.48{ }^{\circ} \mathrm{C}$ in the dry season which may explain the increase in the temperature gradient at the station.

It is considered important that research in this area should be encouraged so that they may reveal new knowledge on the studied topic.

\section{REFERENCES}

ABU-HAMDEH, N. H., KHDAIR, A. I., REEDER, R. C. A comparison of two methods used to evaluate thermal conductivity for some soils. International Journal of Heat and Mass Transfer, v. 55, n. 5, p. 1073-1076, 2001.

AMADOR, G. A. Composicion floristic and structural characterization of two areas of carandazais in the subregions of Nabileque and Miranda, south Pantanal of Mato Grosso, Brazil. 2006. Dissertação (Mestrado em Ecologia e Conservação), Universidade Federal de Mato Grosso do Sul. 55p (in Portuguese)

ARAUJO, R. L. C.; SILVA, R. M.; CARVALHO, J. S.; MONTEIRO, I. B. Environmental influence on the structure of shallow geothermal. Brazilian Journal of Geophysics. v. 22, n.1, p. 33-44. 2004 (in Portuguese),

BELLAVER, V. Thermal diffusivity of soil in Area monodominant Cambará In northern Pantanal. 2010. Dissertação (Mestrado em Física Ambiental), Universidade Federal de Mato Grosso. 70p (in Portuguese)

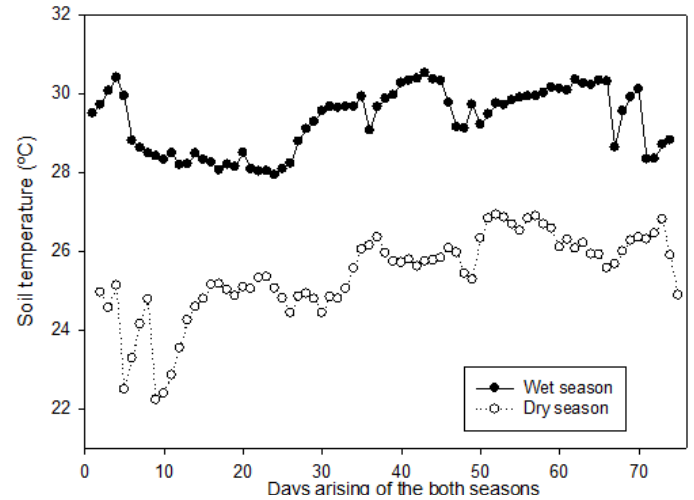

Figure 5 - Variation of the temperature in the $0,07 \mathrm{~m}$ depth in the wet and dry seasons.

CURADO, L. F. A.; RODRIGUES, T. R.; NOVAIS, J. W. Z.; de OLIVEIRA, A. G.; VENTURA, T. M.; DE MUSIS, C. R.; NOGUEIRA, J. S. Adjustment of Brunt's Equation Parameters for the Northern Brazilian Pantanal. Journal of ecology and the Natural Environment. v. 3, n.4, p. 157-162, 2011.

EMBRAPA. National Center for Research in soils. Manual of Methods of Soil Analysis. $2^{\mathrm{a} e d . ~ R i o ~ d e ~ J a n e i r o, ~ 212 p, ~}$ 1997. (in Portuguese)

REICHARDT, K.; TIMM, L.C. Plant, Soil and Atmosphere: Concepts, Processes and Applications, Barueri, SP: Manole. p.50. 2004. (in Portuguese)

SCHÖFFEL, E. R.; MENDES, M. E. G. Influence of coverage on the vertical profile of soil temperature. In XIV Brazilian Congress of Agrometeorology. In XIV Congresso Brasileiro de Agrometeorologia, Piracicaba. São Paulo Anais, 2005.

WANTZEN, K.M. Physical pollution: effects of gully erosion on benthic invertebrates in a tropical clear-water stream. Aquatic Conservation, v. 16, p. 733-749, 2006.

ZEILHOFER, P., LIMA, E.B.N.R., LIMA, G.A.R. Spatial patterns of water quality in the Cuiabá River Basin, Central Brazil. Environment Monitoring and Assessment, v. 123, p. 41-62, 2006.

ZUCARELI, V., AMARO, A. C. E., SILVÉRIO, E. V., FERREIRA G. Métodos de superação da dormência e temperatura na germinação de sementes de Dioclea violácea. Semina Ciências Agrárias, v. 31, n. 1, p. 1305-1312, 2010. 